\title{
PRIORITISING THE PRACTICES THAT INFLUENCE THE OPERATIONAL PERFORMANCE OF MANUFACTURING ORGANISATIONS USING HYBRID AHP-TOPSIS ANALYSIS
}

\author{
A. Arshad Ali ${ }^{1}$, A. Mahmood ${ }^{2 *} \&$ A. Salam ${ }^{3}$
}

\section{ARTICLE INFO}

\section{Article details}

Submitted by authors

4 Jul 2019

Accepted for publication 21 Feb 2020

Available online

\section{Contact details}

Corresponding author asif.mahmood@namal.edu.pk

\section{Author affiliations}

1 Institute of Quality and Technology Management, University of the Punjab, Pakistan

2 Department of Business Studies, $30 \mathrm{Km}$ Talagang Road, Mianwali, Pakistan

3 Department of Metallurgy and Materials Engineering, University of the Punjab, Pakistan

DOI

http://dx.doi.org/10.7166/31-1-2199

\section{ABSTRACT}

Organisations cannot put their efforts equally into all the best practices that impact operational performance, due to their limited resources, their ineffective usage, government policies, and inadequate strategic planning. In this contribution, we aim to identify and prioritise the practices with the most impact on operational performance. Twelve practices that steer operational performance were identified through a literature survey. Second, the identified practices were prioritised and evaluated, based on improving operational performance by using a hybrid approach. The analytical hierarchy process (AHP) and the technique for order performance by similarity to ideal solution (TOPSIS) method were used such that AHP was applied to determine the relative weights of alternatives, and then the final ranking was obtained by conducting a TOPSIS analysis. Empirical data were collected from eight experts and 417 users at operational-level. The results suggest that lean management, total quality management, six sigma, and supply chain management practices rank $1^{\text {st }}$, $2^{\text {nd }}, 3^{\text {rd }}$, and $4^{\text {th }}$ respectively, signifying the practices with the most influence and making the greatest contribution. This strategic understanding will help researchers and practitioners to frame competitive strategies in order to pay more attention to those practices that have a greater influence on operational performance.

\section{OPSOMMING}

Verskeie faktore lei daartoe dat organisasies nie hul toewyding eweredig aan beste praktyke kan bestee nie. Hierdie faktore sluit in: beperkte hulpbronne, en hul ondoeltreffende aanwending, regeringsbeleid en onvoldoende strategiese beplanning. Hierdie artikel poog om die praktyke wat die grootste impak op operasionele vertoning het te identifiseer en te geprioritiseer. Twaalf praktyke wat operasionele vertoning aanvoer is identifiseer deur ' $n$ literatuurstudie. Daarna is hierdie praktyke prioritiseer en evalueer aan die hand van hul vermoë om operasionele vertoning te verbeter deur middel van ' $n$ hibriede benadering. 'n Analitiese hiërargieproses (AHP) en die tegniek vir orde vertoning deur ooreenstemming met die ideale oplossing (TOPSIS) is gebruik. AHP het die relatiewe gewigsfaktore toegeken en die finale rangorde is met behulp van TOPSIS bepaal. Empiriese data is ingesamel van agt kundiges en 417 operasionele gebruikers. Die resultate toon dat lenige bestuur, totale gehalte bestuur, ses-sigma, en voorsieningskettingbestuur onderskeidelik die eerste tot vierde plekke beklee. Die strategiese verstaan van hierdie resultaat sal navorsers en praktisyns help om mededingende strategieë te formuleer en sorg dat hulle meer aandag aan die sleutel praktyke bestee.

\section{INTRODUCTION}

In developing countries, the success of manufacturing organisations plays a significant role in economic development, gross domestic product (GDP) growth, reducing poverty, and creating jobs, because there is a large number of personnel in manufacturing organisations in developing countries [1]. For a nation's 
economy, the manufacturing sector is a growth engine. The growth of the manufacturing sector has a favourable relationship with value-added quality of life and improved earning capacity.

In the current era of globalisation and competitiveness, different practices play an important role in the survival of any firm and in sustaining its long-term performance. In order to compete globally, an organisation must embrace all performance measures and sharpen its functionality and processes [2]. Therefore the main objective of an organisation should be to improve its operational performance (OP) [1]. However, the problem with manufacturing organisations is that OP is not satisfactory due to changing customer expectations, a growing demand for innovativeness, volatility in the market, increasing complexity and uncertainty, and autocratic leadership style in the current era of intense global competition $[1,3]$. In manufacturing facilities, different OP measures are cost, quality, delivery, rate of introduction of a new product, and flexibility $[4,5]$. There are a number of practices that impact OP, but organisations cannot put their efforts equally into all these practices.

Past studies have discussed the impact of different practices individually on OP, such as human resource management, supply chain management, enterprise resource planning, and total quality management practices, but have overlooked the investigation of comparative effects. So there is a dearth of literature that discusses those practices that have a major impact on enhanced OP, and this area remains unexplored. There is thus a need to identify and monitor such practices for performance optimisation and competitiveness with the available resources. Selecting and identifying the most influential alternatives involves complex decisions. This complexity can be resolved by using a multi-criteria decision-making (MCDM) approach [6]. Determining the overall preferences among alternative options is the aim in the MCDM approach [7]. Two MCDM methods - analytical hierarchy process (AHP) and the technique for order performance by similarity to ideal solution (TOPSIS) - have been integrated in the current study to rank the identified practices in order to allocate an organisation's scarce resources.

\section{LITERATURE REVIEW}

Different practices that need to be considered and implemented in manufacturing organisations were identified in the current literature. These practices were represented as critical success factors, and were prioritised according to their importance in the evaluation of OP. The literature was analysed from the perspective of practices that influence the performance of manufacturing organisations, and this was then validated through discussion with the academics and practitioners. A refined list of 12 practices, with their related references, is presented in Table 1. Using AHP and TOPSIS, an assessment for preference order and priority ranking was carried out on the 12 identified practices.

Table1: Literature support for the identified practices

\begin{tabular}{|c|l|c|c|}
\hline Practice no. & \multicolumn{1}{|c|}{ Practices } & Abbreviations & Supported by \\
\hline P1 & Human resource management & HRM & {$[8-10]$} \\
\hline P2 & Supply chain management & SCM & {$[11-13]$} \\
\hline P3 & Organisational culture & OC & {$[14-15]$} \\
\hline P4 & Innovation & INV & {$[16-18]$} \\
\hline P5 & Knowledge management & KM & {$[19-21]$} \\
\hline P6 & Total quality management & $6 \sigma$ & {$[22-24]$} \\
\hline P7 & Six sigma & LM & {$[2,25-26]$} \\
\hline P8 & Lean management & QMS & {$[5,27-28]$} \\
\hline P9 & ISO 9001 (Quality management system) & R\&D & {$[29-30]$} \\
\hline P10 & Research \& development & CM & {$[31-32]$} \\
\hline P11 & Change management & ERP & {$[35-34]$} \\
\hline P12 & Enterprise resource planning system & & \\
\hline
\end{tabular}

\subsection{Identification of best practices}

This section briefly discusses the short-listed practices that have the greatest impact on the OP of manufacturing organisations.

\subsubsection{Human resource management}

The present authors have found in their research that different HRM practices have an impact on performance in any business. OP may include unit cost, delivery, quality, flexibility, or how speedily the new product is introduced in the market; and an intangible performance, such as commitment of an organisation [8]. In today's business environment, operational management is more important than financial performance, because operational measurements include customer satisfaction, innovation, and improved internal processes, which lead to future financial returns [9]. In the past, most research was 
conducted to analyse the impact of HRM practices on organisational performance, but there is a scarcity of literature that discusses the effect of these practices on OP (cost, quality, flexibility, and delivery). In both manufacturing and services organisations, the management of human resources is equally important for enhancing OP [8, 9]. Different HRM practices, such as teamwork, training and development, human resource planning, and performance appraisal, lead to an improved operational and financial performance. Because of these practices, an organisation can retain skilled and talented personnel, which, in turn, leads to its competitiveness [10].

\subsubsection{Supply chain management}

These days, the real competitors are the supply chains rather than individual organisations. The OP of manufacturing organisations is influenced by supply chain management (SCM) practices, which are regarded as fundamental to performance improvement in any organisation [11]. Four practices in the SCM construct are long-term relationships, information-sharing, cooperation, and process integration. The SCM construct has a positive and significant relationship with all dimensions of OP [12]. Tatoglu, Bayraktar, Golgeci, Koh, Demirbag and Zaim [13] also confirmed that SCM practices have a significant impact on the OP of small and medium enterprises (SMEs).

\subsubsection{Organisational culture}

It is agreed that, when employees feel good, they deliver. That is why business leaders always want to create an organisational culture in which there is enjoyment, flexibility in working hours, and creativity. Shared beliefs, values, and assumptions in an organisation make an organisation's culture. Different types of organisational culture have diverse effects on performance. For example, a competitive and innovative culture has a strong, significant, and direct impact on a firm's performance [14]. Others, such as a group culture and a rational culture, have a direct impact; a developmental culture has an indirect relationship with OP; and hierarchical culture has both a direct and an indirect influence on OP [15].

\subsubsection{Innovation}

To gain a competitive edge in the current era of globalisation, innovation or an idea-creation process is an essential element. Product innovation, process innovation, and overall organisational innovation are three different kinds of innovation. In manufacturing organisations, a focus on process innovation is recommended to improve OP [16]. Saunila [17] said that product innovation and process innovation are included in technological innovation, and there is a positive and significant association between technological innovation and the performance of an organisation. The study of Calantone, Cavusgil and Zhao [18] also confirms the findings of previous literature - that process innovation influences OP to such an extent that it must be there for survival in such a volatile environment.

\subsubsection{Knowledge management}

Core competency and superior performance can be obtained in any organisation if there are one or more value-added disciplines in that organisation. Knowledge management (KM) is a value-added approach that enhances organisational competitiveness. Knowledge management is a complicated process, and can be explained as how a firm can acquire and disseminate knowledge or information. Competitiveness and better performance can be achieved if a firm is able to acquire external critical knowledge faster than its competitors. Similarly, knowledge dissemination plays an important role in achieving better performance through the mechanism of knowledge diffusion, as employees gain access to the required knowledge. Codification and personalisation knowledge management strategies are the two main strategies with a direct and indirect (through innovation) relationship with performance [19]. Enhanced technical and administrative innovation performance may be achieved by facilitating the dynamics of knowledge acquisition, sharing, and application, all of which lead to favourable organisational performance. It means that the relationship between KM and OP is mediated by innovation performance [20]. Fugate, Stank and Mentzer [21] also observed that there is a positive relationship between the active participation of logistics operations personnel in knowledge process behaviour and OP. Therefore, in order to be more innovative, productive, and competitive, an organisation needs effectively and strategically to manage its knowledge resources.

\subsubsection{TQM practices}

To compete internationally, quality is a powerful strategic weapon. Improvement in quality has become a prerequisite for achieving competitiveness; and OP plays an important role in gaining this competitive advantage [22]. In the literature, there is enough consideration of the relationship between TQM and OP in this era of fierce competition. The major variance in OP (57 per cent) is because of quality management practices [23]. Some authors showed the impact of techniques and tool-oriented TQM practices (called 'hard TQM practices') on the quality and inventory management performance dimensions of OP. Continuous improvement, statistical process control (SPC), process management, and quality tools and techniques are hard TQM practices. All of these have an impact on the OP of manufacturing organisations. But to obtain 
the desired results of OP, SPC and continuous improvement are more significant than other hard TQM practices [24].

\subsubsection{Six sigma}

In 1985, the 'six sigma' concept was invented by Motorola Inc., partly due to the threat of Japanese competition. In manufacturing organisations, six sigma plays an important role in reducing costs and defects, enhancing employee satisfaction, and improving customer satisfaction; these are the dimensions of OP. Achieving the objectives of six sigma has to be long-term [2, 25]. Achieving fewer than 3.4 defects per million opportunities is the target of six sigma, and many organisations claim that having a six sigma programme is better for business [26]. The implementation of lean and six sigma has a strong relationship with operational and financial performance [25].

\subsubsection{Lean management}

Lean thinking is very important in the entire supply chain. Its main purposes are to eliminate waste and enhance competitiveness. Lean also means more production with fewer resources. Lean manufacturing (LM) originated on the shop floor of Toyota, with the names 'Toyota production system' (TPS) or just-in-time (JIT) manufacturing [5]. Therefore LM, JIT, and TPS are used interchangeably because of their similar practices. The practices included in $L M$ are positively and directly associated with OP and business performance (BP), and indirectly associated with BP through OP as a mediator [27]. As the idea behind lean manufacturing is to produce the right items in the right quantity and at the right time with a well-designed equipment layout, it could reduce the level and cost of inventory, which leads to enhanced competitiveness and improved performance. Even the partial implementation of lean practices makes a significant contribution to an organisation's OP [28].

\subsubsection{ISO 9001 (QMS)}

The International Organization for Standardization (ISO) created the family of ISO 9000 standards, which are related to the most modern technology and practices. The ISO 9001 standard was revised in 1994, 2000, 2008, and 2015 after considering the requirements of companies and the market, and to make it more responsive. ISO 9001 certification most often becomes a necessity for the continuity of business relationships, because the main reasons for seeking ISO 9001 certification are customer demand and satisfaction [29]. If QMS (ISO 9001) is well-planned and implemented in its true sense, the OP of organisations will improve. The operational and financial performance of ISO 9001 -certified manufacturing organisations is significantly better than that of non-certified firms [30].

\subsubsection{Research and development}

Discovering new knowledge about existing or new services, products, or processes is the result of research and development (R\&D) activities. Restructuring the current knowledge and producing new knowledge in an organisation is called its R\&D capability. To some extent there is investment in R\&D in every kind of organisation. R\&D practices have a significant relationship with the OP of manufacturing organisations; but this relationship is moderated by intellectual property rights (IPR), showing that this relationship cannot be generalised to all manufacturing sectors [31]. Investment in an R\&D department is positively associated with the operational and financial performance of an organisation. R\&D is an explanatory variable of performance, and this investment (an intangible asset) in R\&D is very important for the success and even for the survival of an organisation [32].

\subsubsection{Change management}

In the current era there is intense competition because of continuous and inevitable changes in customer taste, services, products, and technology. Any new ways of working or any new processes are included in an organisation as a regular feature. As change is important, management of that change is also imperative in order to avoid resistance. By using change strategies, the OP of an organisation can be enhanced through the successful management of change. There are different strategies for managing different changes, and the strengths and weaknesses of any strategy must be known before its adoption. Not only do cost reduction and quality improvement relate to operational excellence, but the handling of people and resources is also a component. Strong leadership and a strong change management capability is required to achieve operational excellence [33]. And employees' strong commitment to change is a condition for a significant and positive relationship between the management of different change factors and an organisation's operational excellence [34].

\subsubsection{Enterprise resource planning (ERP) system}

ERP systems may be considered a means or tool for improving OP. Human resource, finance, asset, operation, distribution, and stock management are different modules of an ERP approach. After implementing the different modules of an ERP system, the performance of an organisation improves in its quality and the availability of information, cost reduction, cycle time reduction standardisation, inventory management, and on-time delivery, because an ERP system automates the business processes [35]. Besides 
controlling cost, the introduction and development of a new offering may also be possible because of an ERP system [36].

The foregoing practices play an important role in the OP of an organisation, but it is very difficult to attend fully to all of these practices at the same time. So it is essential to recognise those practices that are crucial to enhancing performance metrics if limited resources are to be used wisely.

\section{3}

\section{RESEARCH METHODOLOGY}

Through interviewing practitioners and professors from different universities who are knowledgeable in the field of the OP of manufacturing organisations, the list of identified practices from the existing literature was examined. There was consensus among all the professors and practitioners that the selected practices are reasonable and significant.

In the present study, the technique used to gain a better understanding of the 12 identified practices was an integrated AHP-TOPSIS. In 1980, Prof. Thomas L. Saaty [37] developed a multi- criteria decision-making approach called the analytical hierarchy process (AHP). Both quantitative and qualitative criteria are incorporated into it in a meaningful way, and pair-wise comparisons are made. AHP is useful for assigning weights and for evaluating the relative importance of each practice when there are conflicting criteria. In this way, it structures the hierarchy of a problem. The consistency ratio is also computed in AHP to determine whether or not the pair-wise comparisons are consistent. In TOPSIS, the weights obtained from AHP are used as inputs to rank the identified alternatives or practices through distance measures [38]. The use of AHP and TOPSIS is illustrated below.

\subsection{AHP}

The steps of AHP are as follows [37, 38]:

Step 1: After setting the goal, the decision hierarchy is structured from the top, through the intermediate level, to the bottom level. The first level is about prioritising the practices of OP. In the second level, there are groups of all the practices based on their attributes. The last level is about alternatives or practices from which the most influential practices have to be selected.

Step 2: In this step, experts are solicited using a 1-9 preference scale (Table 2) to create matrices of pairwise comparisons of all the practices and groups.

Step 3: To normalise each matrix, the mathematical process starts. There is a division of each entry in the column of a matrix by its respective column sum, and a normalised matrix is obtained. By taking the average of all values in a row of the normalised matrix, the eigenvector of the matrix (the relative weight of each element) is obtained. Then, through the summation of the product of the eigenvector and the sum of the columns of the reciprocal matrix, the largest or principal eigenvalue, known as $\lambda_{\max }$, is obtained.

Step 4: To verify the assessment of a decision group, a consistency test is conducted by using this formula:

$$
\begin{aligned}
& C R \text { (Consistency Ratio })=\frac{C I}{R I} \\
& \text { where RI = Random index, and } \\
& C I \text { (Consistency Index) }=\frac{\lambda_{\max }-n}{n-1}
\end{aligned}
$$

where $\mathrm{n}$ is the size of the matrix and the value of $\mathrm{Rl}$ is obtained from the random inconsistencies index (Table 3 ) given below. For example, the value of RI for a $4 \times 4$ matrix is 0.89 .

If the value of $C R>0.1$, it shows that there is not a proper comparison of the elements and a review is needed. 
Table 2: The fundamental preference scale of absolute numbers [39]

\begin{tabular}{|c|c|c|}
\hline $\begin{array}{l}\text { Intensity of } \\
\text { importance }\end{array}$ & Definition & Explanation \\
\hline $\begin{array}{l}1 \\
2\end{array}$ & $\begin{array}{l}\text { Equal importance } \\
\text { Weak or slight }\end{array}$ & Equal contribution of two activities to the objective \\
\hline 3 & Moderate importance of one over another & $\begin{array}{l}\text { Slightly favouring one activity over another on the } \\
\text { basis of judgement and experience }\end{array}$ \\
\hline 4 & Moderate plus & \\
\hline 5 & Strong importance & $\begin{array}{l}\text { Judgement and experience strongly favour one } \\
\text { activity over another }\end{array}$ \\
\hline $\begin{array}{l}6 \\
7 \\
8\end{array}$ & $\begin{array}{l}\text { Strong plus } \\
\text { Demonstrated importance or very strong } \\
\text { Very, very strong }\end{array}$ & Very strong favouring of one activity over another \\
\hline 9 & Extreme importance & $\begin{array}{l}\text { The evidence favouring one activity over another is of } \\
\text { the highest possible order of importance }\end{array}$ \\
\hline $\begin{array}{l}\text { Reciprocals } \\
\text { of above }\end{array}$ & $\begin{array}{l}\text { If activity } i \text { has one of the above non-zero } \\
\text { numbers assigned to it when compared } \\
\text { with activity } j \text {, then } j \text { has the reciprocal } \\
\text { value when compared with } i\end{array}$ & A reasonable assumption \\
\hline $1.1-1.9$ & If the activities are very close & $\begin{array}{l}\text { May be difficult to assign the best value, but when } \\
\text { compared with other contrasting activities, the size of } \\
\text { the small numbers would not be too noticeable; yet } \\
\text { they can still indicate the relative importance of the } \\
\text { activities }\end{array}$ \\
\hline
\end{tabular}

Table 3: Random consistency index [40]

\begin{tabular}{lllllllll}
\hline $\mathbf{n}$ & 1 & 2 & 3 & 4 & 5 & 6 & 7 & 8 \\
$\mathbf{R I}$ & 0 & 0 & 0.52 & 0.89 & 1.11 & 1.25 & 1.35 & 1.4 \\
\hline $\mathbf{n}$ & 9 & 10 & 11 & 12 & 13 & 14 & 15 & \\
$\mathbf{R I}$ & 1.45 & 1.49 & 1.52 & 1.54 & 1.56 & 1.58 & 1.59 & \\
\hline
\end{tabular}

\subsection{TOPSIS}

TOPSIS (technique for order performance by similarity to ideal solution) was developed by Hwang and Yoon in 1981 [41]. The primary concept in the TOPSIS approach is that the most preferred alternative or practice should have the shortest distance from the positive ideal solution (PIS) and the farthest distance from the negative ideal solution (NIS) [6]. The relative advantage of TOPSIS is that the best alternative is quickly identified, and that only limited subjective input is needed from decision-makers. The PIS minimises the cost criteria and maximises the benefit criteria, whereas NIS does the opposite. All the best values are included in the PIS, and all the worst values attainable from the criteria are included in the NIS [42]. The following steps are involved in TOPSIS:

Step 1: Form a decision matrix, and then normalise that decision matrix. $\boldsymbol{r}_{i j}$ represents the normalised value, calculated as:

$$
r_{i j}=\frac{x_{i j}}{\sqrt{\sum x_{i j}^{2}}}
$$

where

$$
\begin{aligned}
& \mathrm{i}=1, \ldots ., \mathrm{m} \text { and } \mathrm{j}=1, \ldots . ., \mathrm{n} \\
& \boldsymbol{x}_{\boldsymbol{i j}}=\text { original decision matrix, and } \\
& \boldsymbol{r}_{\boldsymbol{i}}=\text { normalised decision matrix }
\end{aligned}
$$

Step 2: In this step, the weighted normalised decision matrix is constructed by multiplying each column of matrix $r_{i j}$ by weight wj.

$$
\begin{gathered}
\boldsymbol{v}_{\boldsymbol{i j}}=\boldsymbol{r}_{\boldsymbol{i j}} \times \boldsymbol{w}_{\boldsymbol{j}} \\
\text { for } \mathrm{i}=1, \ldots . ., \mathrm{m} \text { and } \mathrm{j}=1, \ldots \ldots, \mathrm{n}
\end{gathered}
$$

where $w_{j}$ is the weight obtained from AHP in the current study. 
Step 3: The positive ideal solution $\mathrm{V}+$ and the negative ideal solution $\mathrm{V}$ - are determined in this step. In each column of the weighted normalised decision matrix, all the maximum and minimum values denoted by $A_{+}$and $A_{-}$are respectively the positive ideals and negative ideals.

$$
\begin{aligned}
& A_{+}=\left\{\left(\max \left(v_{i j} \mid \mathbf{i}=\mathbf{1}, 2, \ldots, \mathbf{m}\right) \mid j \in J_{-}\right),\left(\min \left(v_{i j} \mid \mathbf{i}=\mathbf{1}, \mathbf{2}, \ldots, \mathbf{m}\right) \mid j \in J_{+}\right)\right\} \\
& A_{-}=\left\{\left(\min \left(v_{i j} \mid \mathbf{i}=1,2, \ldots, \mathbf{m}\right) \mid j \in J_{+}\right),\left(\max \left(v_{i j} \mid \mathbf{i}=1,2, \ldots, \mathbf{m}\right) \mid j \in J_{-}\right)\right\}
\end{aligned}
$$

where $J_{+}$is linked with the criteria of positive impact and $J_{-}$is linked with the criteria of negative impact.

Step 4: The separation measure is calculated for each alternative. From the positive ideal alternative, the separation is calculated as:

$$
S_{+}^{i}=\sqrt{\sum_{j=1}^{m}\left(v_{i j}-v_{j}^{+}\right)^{2}}, i=1,2,3 \ldots, m
$$

$S_{+}^{i}$ stands for distance i from positive ideal

The calculation of the separation from the negative ideal alternative is

$$
S_{-}^{i}=\sqrt{\sum_{j=1}^{m}\left(v_{i j}-v_{j}^{-}\right)^{2}}, i=1,2,3 \ldots, m
$$

$S_{-}^{i}$ stands for the distance i from the negative ideal

Step 5: The relative closeness to the ideal solution is computed here, and it is defined for each alternative as:

$$
C_{i}=\frac{S_{-}^{i}}{S_{-}^{i}+S_{+}^{i}}
$$

Step 6: In decreasing order of preference, rank the practices based on the relative closeness values. In the TOPSIS method, the chosen alternative should have the shortest distance from the positive ideal solution and the longest distance from the negative ideal solution.

\section{NUMERICAL APPLICATION OF THE PROPOSED MODEL, AND RESULTS}

Applying the proposed model in manufacturing organisations means assessing the most influential practices, thus making it helpful for decision-makers. The practices that contribute and influence the most improve the OP of manufacturing organisations significantly; but selecting the most influential practices - from among numerous alternatives/practices that dominate each other in different characteristics - is very difficult. Based on the steps provided in the previous section, the numerical applications with their results have been described.

\subsection{Computation of weights}

A panel of ten experts, consisting of five professors from different universities and five senior managers from diverse manufacturing organisations with at least 10 years of experience, was consulted to make the judgements among all the practices while applying AHP. Depending on the participants' experience, knowledge, and information about the topic, the primary data were obtained through expert elicitation. Nine questionnaire forms were received out of the ten that were circulated. After analysing the nine questionnaires, the responses of eight of the experts were found to be consistent.

A three-level hierarchy structure of different practices for the AHP analysis was developed. On the first level, the goal was to identify those practices that contributed and influenced the most. At the second level, all the practices were placed in three groups. At the third level were all the practices that impact $\mathrm{OP}$, from which the most influential practices were selected. Through the use of a fundamental preference scale of absolute numbers, as shown in Table 2, pairwise comparisons of practices and of groups were conducted, keeping in mind the objective of OP enhancement. All the comparison matrices were of a good consistency because all the CR values were less than 0.1 . The assigned and normalised weights of all the practices representing the relative importance of each individual practice were obtained (using the experts' judgement), as shown in column 11 of Table 4. Concerning the improvement in the OP of manufacturing 
organisations, group 1 - which is about different quality concepts having a relative preference weight of 0.5166 - is believed to be of the greatest importance. These practices under group 1 show their relatively high importance: LM, TQM, Six Sigma, and ISO 9001 have relative preference weights of 0.2893, 0.0970, 0.0771 , and 0.0378 respectively. Group 2 , with a relative preference weight of 0.1928 , played the second most important role in the improvement of OP. Global preference weights of group 2 practices such as SCM, HRM, ERP and change management are 0.0586, 0.0378, 0.0348, and 0.0198 respectively. ISO 9001 and HRM practices have an equal weight of 0.0378 and occupy the middle position within all the practices. The relative preference weight of the $3^{\text {rd }}$ group was 0.1153 . Organisational culture, a factor of the $3^{\text {rd }}$ group, occupies the global preference weight of 0.0407 . There are more pronounced weight differences between the groups than there are differences between practices. In the TOPSIS method, these weights are used (shown in Table 7) to identify the most influential and contributory practices.

\subsection{Evaluation of practices, and determination of final ranking}

While using TOPSIS in the current study, a questionnaire based on the 12 practices influencing the OP of manufacturing organisations was developed. The questionnaires were distributed to 695 users (managers and supervisors) at the operational level of different manufacturing organisations, who were asked to respond on a five-point Likert scale, ranging from 'strongly disagree' (1) to 'strongly agree' (5). Sixty per cent $(60 \%)$ of the respondents answered the questions in the instrument, and the rest did not complete the survey. After discarding incomplete questionnaires, 417 users had completely fulfilled the questionnaire requirements for this study. Based on the information provided by the users, the decision matrix was prepared (shown in Table 5), which illustrates the importance of the different practices according to their impact on OP. The decision matrix was then normalised using equation (1), as shown below in Table 6.

Table 4: The importance weights of all practices (comparing the priority vectors of all the questionnaires)

\begin{tabular}{|c|c|c|c|c|c|c|c|c|c|c|}
\hline Practices & Expert 1 & Expert 2 & Expert 3 & Expert 4 & Expert 5 & Expert 6 & Expert 7 & Expert 8 & $\begin{array}{c}\text { Relative } \\
\text { preference } \\
\text { weights } \\
\text { (geometric } \\
\text { mean) }\end{array}$ & $\begin{array}{c}\text { Global } \\
\text { preference } \\
\text { weights }\end{array}$ \\
\hline \multicolumn{9}{|c|}{ Group 1} & 0.5166 & \\
\hline LM & 0.4656 & 0.6139 & 0.6217 & 0.5656 & 0.5497 & 0.4850 & 0.6408 & 0.5634 & 0.5600 & 0.2893 \\
\hline QMS & 0.0957 & 0.0591 & 0.1410 & 0.0584 & 0.0886 & 0.0479 & 0.0681 & 0.0605 & 0.0731 & 0.0378 \\
\hline $6 \sigma$ & 0.1609 & 0.1961 & 0.1618 & 0.1439 & 0.1349 & 0.1795 & 0.1106 & 0.1248 & 0.1492 & 0.0771 \\
\hline TQM & 0.2778 & 0.1309 & 0.0755 & 0.2321 & 0.2269 & 0.2876 & 0.1805 & 0.2513 & 0.1878 & 0.0970 \\
\hline C.I & 0.0104 & 0.0498 & 0.0270 & 0.0138 & 0.0582 & 0.0191 & 0.0259 & 0.0402 & 0.0262 & \\
\hline C.R & 0.0116 & 0.0553 & 0.0300 & 0.0154 & 0.0646 & 0.0212 & 0.0288 & 0.0447 & 0.0292 & \\
\hline \multicolumn{9}{|c|}{ Group 2} & 0.1928 & \\
\hline $\mathrm{HRM}$ & 0.1169 & 0.6372 & 0.2864 & 0.0777 & 0.1975 & 0.0891 & 0.1377 & 0.5423 & 0.1960 & 0.0378 \\
\hline SCM & 0.4868 & 0.1828 & 0.0479 & 0.5097 & 0.6122 & 0.5160 & 0.4573 & 0.2333 & 0.3041 & 0.0586 \\
\hline ERP & 0.3041 & 0.1053 & 0.0920 & 0.3605 & 0.0746 & 0.3371 & 0.2998 & 0.1397 & 0.1803 & 0.0348 \\
\hline C.M & 0.0922 & 0.0747 & 0.5736 & 0.0520 & 0.1157 & 0.0577 & 0.1052 & 0.0847 & 0.1029 & 0.0198 \\
\hline C.I & 0.0474 & 0.0535 & 0.0767 & 0.0344 & 0.0238 & 0.0233 & 0.0448 & 0.0171 & 0.0360 & \\
\hline C.R & 0.0527 & 0.0594 & 0.0852 & 0.0382 & 0.10265 & 0.0259 & 0.0497 & 0.0190 & 0.0474 & \\
\hline \multicolumn{9}{|c|}{ Group 3} & 0.1153 & \\
\hline O.C & 0.5312 & 0.3247 & 0.4137 & 0.1408 & 0.5154 & 0.1649 & 0.5568 & 0.5078 & 0.3534 & 0.0407 \\
\hline INV & 0.2795 & 0.5221 & 0.4038 & 0.0920 & 0.3126 & 0.0642 & 0.1573 & 0.2410 & 0.2117 & 0.0244 \\
\hline R\&D & 0.0969 & 0.0939 & 0.1121 & 0.3421 & 0.0838 & 0.2923 & 0.1875 & 0.1485 & 0.1486 & 0.0171 \\
\hline K.M & 0.0925 & 0.0593 & 0.0704 & 0.4252 & 0.0882 & 0.4786 & 0.0983 & 0.1026 & 0.1275 & 0.0147 \\
\hline C.I & 0.0015 & 0.0680 & 0.0542 & 0.0521 & 0.0072 & 0.0113 & 0.0826 & 0.0663 & 0.0245 & \\
\hline C.R & 0.0016 & 0.0756 & 0.0602 & 0.0579 & 0.0080 & 0.0126 & 0.0917 & 0.0737 & 0.0271 & \\
\hline
\end{tabular}

Table 5: Initial decision matrix

\begin{tabular}{|l|c|c|c|c|c|}
\hline Alternatives/Practices & $\boldsymbol{X}_{\boldsymbol{i}} \mathbf{5}$ & $\boldsymbol{X}_{\boldsymbol{i}} \mathbf{4}$ & $\boldsymbol{X}_{\boldsymbol{i}} \mathbf{3}$ & $\boldsymbol{X}_{\boldsymbol{i}} \mathbf{2}$ & $\boldsymbol{X}_{\boldsymbol{i}} \mathbf{1}$ \\
\hline Lean management & 171 & 167 & 55 & 19 & 5 \\
\hline Knowledge management & 29 & 113 & 200 & 42 & 33 \\
\hline Change management & 9 & 87 & 167 & 71 & 83 \\
\hline Human resource management & 108 & 171 & 121 & 9 & 8 \\
\hline Total quality management & 183 & 142 & 71 & 17 & 4 \\
\hline ISO 9001 & 183 & 109 & 79 & 37 & 9 \\
\hline Research \& development & 192 & 109 & 83 & 29 & 4 \\
\hline Organisational culture & 122 & 137 & 120 & 25 & 13 \\
\hline Supply chain management & 163 & 146 & 87 & 17 & 4 \\
\hline Innovation & 134 & 171 & 79 & 23 & 10 \\
\hline ERP system & 167 & 133 & 96 & 13 & 8 \\
\hline Six sigma & 158 & 154 & 75 & 25 & 5 \\
\hline
\end{tabular}


Table 6: Normalised decision matrix

\begin{tabular}{|c|c|c|c|c|c|}
\hline Practices & $X_{i} 5 / \sqrt{\Sigma} X_{i j}^{2}$ & $X_{i} 4 / \sqrt{\Sigma} X_{i j}^{2}$ & $X_{i} 3 / \sqrt{\Sigma} X_{i j}^{2}$ & $X_{i} 2 / \sqrt{\Sigma} X_{i j}^{2}$ & $X_{i} 1 / \sqrt{\Sigma} X_{i j}^{2}$ \\
\hline LM & 0.6950 & 0.6787 & 0.2235 & 0.0772 & 0.0203 \\
\hline KM & 0.1220 & 0.4756 & 0.8417 & 0.1768 & 0.1389 \\
\hline$C M$ & 0.0413 & 0.3993 & 0.7665 & 0.3259 & 0.3810 \\
\hline HRM & 0.4576 & 0.7246 & 0.5127 & 0.0381 & 0.0339 \\
\hline TQM & 0.7534 & 0.5846 & 0.2923 & 0.0700 & 0.0165 \\
\hline ISO 9001 & 0.7944 & 0.4732 & 0.3430 & 0.1606 & 0.0391 \\
\hline R\&D & 0.8078 & 0.4586 & 0.3492 & 0.1220 & 0.0168 \\
\hline OC & 0.5520 & 0.6199 & 0.5430 & 0.1131 & 0.0588 \\
\hline SCM & 0.6903 & 0.6183 & 0.3684 & 0.0720 & 0.0169 \\
\hline INV & 0.5763 & 0.7354 & 0.3398 & 0.0989 & 0.0430 \\
\hline ERP system & 0.7119 & 0.5670 & 0.4092 & 0.0554 & 0.0341 \\
\hline $6 \sigma$ & 0.6740 & 0.6569 & 0.3199 & 0.1066 & 0.0213 \\
\hline
\end{tabular}

The normalised decision matrix was then weighted by multiplying it by the weight factor. The computation of the weighted normalised matrix using equation (2) is given below in Table 7 (the weights of all 12 practices were obtained from column 11 of Table 4).

Equations (3) to (6) were used to determine the distance from the positive and negative ideal solutions. By using equations (3) and (4), the positive ideal and the negative ideal were calculated as shown in Table 8.

Table 7: Weighted normalised decision matrix

\begin{tabular}{|l|l|l|l|l|l|}
\hline Practices & $\mathbf{V 5}$ & $\mathbf{V} \mathbf{j}$ & $\mathbf{V} \mathbf{j}$ & $\mathbf{V} \mathbf{j}$ & $\mathbf{V} \mathbf{j}$ \\
\hline LM & 0.19915 & 0.19635 & 0.0647 & 0.0223 & 0.0059 \\
\hline KM & 0.00179 & 0.00699 & 0.0124 & 0.0026 & 0.0020 \\
\hline CM & 0.00082 & 0.00791 & 0.0152 & 0.0065 & 0.0075 \\
\hline HRM & 0.01730 & 0.02739 & 0.0194 & 0.0014 & 0.0013 \\
\hline TQM & 0.07308 & 0.05671 & 0.0284 & 0.0068 & 0.0016 \\
\hline ISO 9001 & 0.03003 & 0.01789 & 0.0130 & 0.0061 & 0.0015 \\
\hline R\&D & 0.01381 & 0.00784 & 0.0060 & 0.0021 & 0.0003 \\
\hline OC & 0.02247 & 0.02523 & 0.0221 & 0.0046 & 0.0024 \\
\hline SCM & 0.04045 & 0.03623 & 0.0216 & 0.0042 & 0.0010 \\
\hline INV & 0.01406 & 0.01794 & 0.0083 & 0.0024 & 0.0010 \\
\hline ERP system & 0.02477 & 0.01973 & 0.0142 & 0.0019 & 0.0012 \\
\hline 60 & 0.05196 & 0.05065 & 0.0247 & 0.0082 & 0.0016 \\
\hline
\end{tabular}

Table 8: Ideal best A+ and Ideal negative A- solution matrix

\begin{tabular}{|l|l|l|l|}
\hline & Ideal (Best) $\mathrm{A}^{+}$ & & Negative ideal A- \\
\hline $\mathrm{Vi1}^{+}$ & 0.19915 & $\mathrm{Vi1}^{-}$ & 0.00082 \\
\hline $\mathrm{Vi2}^{+}$ & 0.19635 & $\mathrm{Vi2}^{-}$ & 0.00699 \\
\hline $\mathrm{Vi3}^{+}$ & 0.06467 & $\mathrm{Vi3}^{-}$ & 0.00597 \\
\hline $\mathrm{Vi}^{+}$ & 0.02234 & $\mathrm{Vi}^{-}$ & 0.00144 \\
\hline $\mathrm{Vi5}^{+}$ & 0.00754 & $\mathrm{Vi}^{-}$ & 0.00029 \\
\hline
\end{tabular}

The Euclidean separation distances given in Table 9 were calculated using equations (5) and (6):

Table 9: Euclidean separation distance

\begin{tabular}{|c|c|c|c|}
\hline Si+ & Distance $i$ from positive ideal & Si- & Distance $i$ from negative ideal \\
\hline $\mathrm{S} 1+$ & 0.0017 & $\mathrm{~S} 1-$ & 0.2813 \\
\hline $\mathrm{S} 2+$ & 0.2792 & $\mathrm{~S} 2-$ & 0.0068 \\
\hline $\mathrm{S} 3+$ & 0.2785 & $\mathrm{~S} 3-$ & 0.0128 \\
\hline $\mathrm{S} 4+$ & 0.2533 & $\mathrm{~S} 4-$ & 0.0295 \\
\hline $\mathrm{S} 5+$ & 0.1923 & $\mathrm{~S} 5-$ & 0.0907 \\
\hline $\mathrm{S} 6+$ & 0.2518 & $\mathrm{~S} 6-$ & 0.0323 \\
\hline $\mathrm{S} 7+$ & 0.2717 & $\mathrm{~S} 7-$ & 0.0130 \\
\hline $\mathrm{S} 8+$ & 0.2503 & $\mathrm{~S} 8-$ & 0.0328 \\
\hline $\mathrm{S} 9+$ & 0.2303 & $\mathrm{~S} 9-$ & 0.0517 \\
\hline $\mathrm{S} 10+$ & 0.2640 & $\mathrm{~S} 10-$ & 0.0174 \\
\hline $\mathrm{S} 11+$ & 0.2542 & $\mathrm{~S} 11-$ & 0.0284 \\
\hline $\mathrm{S} 12+$ & 0.2115 & $\mathrm{~S} 12-$ & 0.0701 \\
\hline
\end{tabular}


By using equation (7), relative closeness ( $\mathrm{Ci}$ ) was computed to the ideal solution for each practice. The $\mathrm{Ci}$ values lie between 0 and 1 , as shown below in Table 10:

Table 10: Relative closeness to the ideal solution for each alternative

\begin{tabular}{|c|l|l|}
\hline $\begin{array}{c}\text { Relative } \\
\text { closeness } \\
\text { Ci }\end{array}$ & \multicolumn{1}{|c|}{ Values } & \multicolumn{1}{|c|}{ Alternatives/practices } \\
\hline C1 & 0.9941 & Lean management \\
\hline C2 & 0.0238 & Knowledge management \\
\hline C3 & 0.0439 & Change management \\
\hline C4 & 0.1042 & Human resource management \\
\hline C5 & 0.3204 & Total quality management \\
\hline C6 & 0.1137 & ISO 9001 \\
\hline C7 & 0.0458 & R\&D \\
\hline C8 & 0.1159 & Organisational culture \\
\hline C9 & 0.1835 & Supply chain management \\
\hline C10 & 0.0618 & Innovation \\
\hline C11 & 0.1005 & ERP system \\
\hline C12 & 0.2490 & Six sigma \\
\hline
\end{tabular}

The calculations of TOPSIS showed that the practices with the maximum $\mathrm{Ci}$ values are the major contributors to the OP of manufacturing organisations. As shown in Figure 1, a summary of the ranking of all practices in the form of a radar plot produces P8-P6-P7-P2-P3-P9-P1-P12-P4-P10-P11-P5, in decreasing order of preference. Practices with larger index values are significant contributors of OP. LM practices are the most influential, with the highest $\mathrm{Ci}$ value of 0.9941 . It is also evident from Table 9 that LM practices have the shortest distance $(0.0017)$ from the positive ideal solution (PIS), and the furthest distance $(0.2813)$ from the negative ideal solution (NIS).

From figure 1 , it is clear that the weight factor influences the ranking order, which shows that the TOPSIS method is more sensitive to the weighting factor.

\section{DISCUSSION}

Selecting the most influential factors affecting $O P$ is a valid concern of managers in this era of competitiveness. The present study has endeavoured to prioritise these enabling factors according to their importance, in order to help decision-makers.

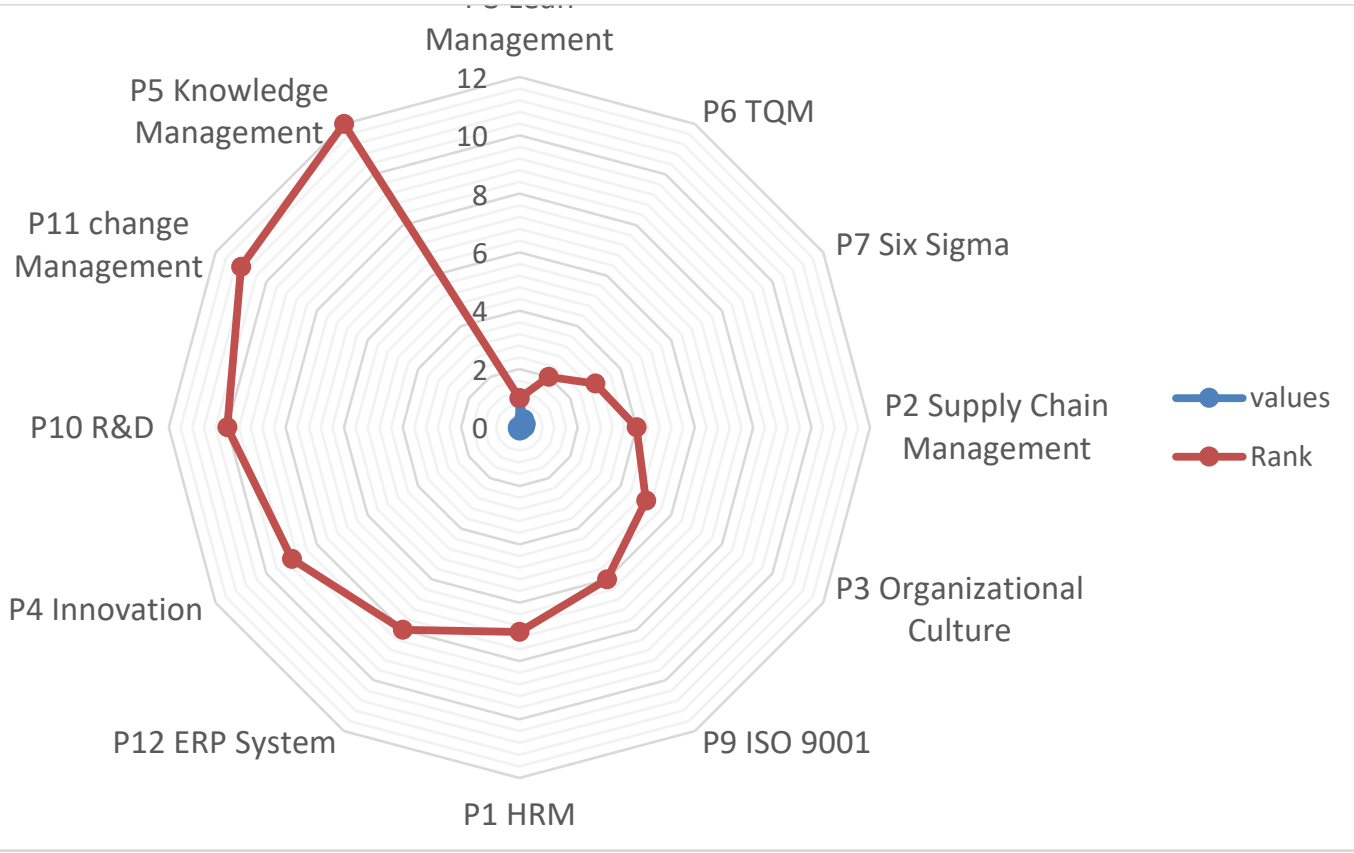

Figure 1: The radar plot showing the ranking results 
The experts' opinions and the literature survey were used, together with MCDM techniques, to make a comparative evaluation of the practices. The practices having the highest relative closeness $(\mathrm{Ci})$ values (obtained through the hybrid AHP-TOPSIS technique) were selected as the most important. Consequently, LM practices were found to be closest to the ideal solution, with TQM, six sigma and SCM filling the $2^{\text {nd }}, 3^{\text {rd }}$, and $4^{\text {th }}$ positions respectively. The results of this study are consistent with the findings of previous studies using different methodologies. For instance, Yadav et al. [23] concluded that the implementation of LM practices explained an 80 per cent variance (a remarkable value) in OP, which supports the common perception of researchers that LM has a positive impact on OP. It is also supported by the results of Panwar et al. [22] - that OP increases with the increase in the extent of LM implementation (adjusted $R^{2}=0.69$ ). The current study also found a positive relationship of TQM with OP. This result is consistent with the conclusions reached by Truong et al. [27], that QM practices explained a 57.1 per cent variance of OP. This finding is also supported by the results of Cerio [26], that a statistically significant relationship exists between a higher level implementation of TQM practices and manufacturing performance. The view that hard TQM practices generate a high OP has also been backed by Saleh, Sweis and Saleh [28]. Studies performed by Alhuraish, Robledo and Kobi [25] are consistent with our findings, as both studies reinforce a strong positive linkage between six sigma and OP. The present study also suggests a high degree of relationship of SCM with performance. Significant efforts have been put into adopting SCM because it is considered a basis for OP improvements; for example, Truong et al. [11] propose a significant and positive relationship between SCM and OP. They state that SCM practices explain a 52.6 per cent variance of OP. The result is supported by the empirical investigation of Miguel and Brito [12]. The overall findings of the research would surely help managers of manufacturing organisations to formulate the corresponding strategies to enhance OP.

\section{CONCLUSION}

Improvement in OP is recognised as a continuous survival strategy in manufacturing organisations. The present work is highly significant, in that it evaluates and selects the practices that impact OP as part of top-level strategic decisions. The importance of weights and the ranking of practices that influence OP have been quantified by using the integrated AHP-TOPSIS technique. To make the application more realistic and reliable, a two-step methodology was structured so that TOPSIS used the AHP weight results as its input weights. On the basis of these weights, the TOPSIS computations determined the alternative priorities. Different quality concepts, such as LM, TQM, six sigma, and ISO 9001 ranked $1^{\text {st }}, 2^{\text {nd }}, 3^{\text {rd }}$, and $6^{\text {th }}$ respectively, while SCM, organisational culture, and HRM practices ranked $4^{\text {th }}, 5^{\text {th }}$, and $7^{\text {th }}$ respectively. The ranking of practices showed that the $\mathrm{CM}$ and $\mathrm{KM}$ practices were the least contributing factors. Therefore more emphasis should be placed on those practices that have high relative importance weights in order to improve the OP of manufacturing organisations.

The present investigation, which provides a systematic framework for the prioritisation of practices, is unique. A unique feature of this study is the use of the hybrid structure of two MCDM techniques to select the practices that are most influential in OP. The present work formulates the development of a decision model for manufacturing organisations. However it could be applicable to other segments with minor modifications. A comparative study could be conducted to validate the results using other techniques. And an interpretive structural modelling (ISM) technique could also be employed to understand the interactions between practices that influence the operational performance of organisations.

\section{REFERENCES}

[1] Ojha, R. K., Vij, A. \& Vrat, P. 2014. Manufacturing excellence and its critical factors: An interpretive structural methodology application. Journal of Advances in Management Research, 11(3), pp. 312-332.

[2] Ertuirk, M., Tuerdi, M. \& Wujiabudula, A. 2016. The effects of six sigma approach on business performance: A study of white goods (home appliances) sector in Turkey. Procedia - Social and Behavioral Sciences, 229, pp. 444452.

[3] Tracey, M., Vonderembse, M.A., \& Lim, J. S.1999. Manufacturing technology and strategy formulation: Keys to enhancing competitiveness and improving performance. Journal of Operations Management, 17(4), pp. 411-428.

[4] Nabass, E. H. \& Abdallah, A. B. 2019. Agile manufacturing and business performance: The indirect effects of operational performance dimensions. Business Process Management Journal, 25(4), pp. 647-666.

[5] Marodin, G. A., Frank, A. G., Tortorella, G. L. \& Fetterman, D. C. 2019. Lean production and operational performance in the Brazilian automotive supply chain. Total Quality Management \& Business Excellence, 30(3-4), pp. 370-385.

[6] Vinodh, S., Prasanna, M. \& Prakash, N. H. 2014. Integrated fuzzy AHP-TOPSIS for selecting the best plastic recycling method: A case study. Applied Mathematical Modelling, 38(19-20), pp. 4662-4672. 
[7] Kabak, M., Burmaoğlu, S. \& Kazançoğlu, Y. 2012. A fuzzy hybrid MCDM approach for professional selection. Expert Systems with Applications, 39(3), 3516-3525.

[8] Ahmad, S. \& Schroeder, R. G. 2003. The impact of human resource management practices on operational performance: Recognizing country and industry differences. Journal of Operations Management, 21(1), pp. 19-43.

[9] Bayo-Moriones, A. \& de Cerio, J. M. D. 2002. Human resource management, strategy and operational performance in the Spanish manufacturing industry. M@ n@ Gement, 5(3), pp. 175-199.

[10] Apospori, E., Nikandrou, I., Brewster, C. \& Papalexandris, N. 2008. HRM and organizational performance in northern and southern Europe. The International Journal of Human Resource Management, 19(7), pp. 1187-1207.

[11] Truong, H. Q., Sameiro, M., Fernandes, A. C., Sampaio, P., Duong, B. A. T., Duong, H. H. \& Vilhenac, E. 2017. Supply chain management practices and firms' operational performance. International Journal of Quality \& Reliability Management, 34(2), pp. 176-193.

[12] De Souza Miguel, P. L. \& Brito, L. A. L. 2011. Supply chain management measurement and its influence on operational performance. Journal of Operations and Supply Chain Management, 4(2), pp. 56-70.

[13] Tatoglu, E., Bayraktar, E., Golgeci, I., Koh, S. L., Demirbag, M. \& Zaim, S. 2016. How do supply chain management and information systems practices influence operational performance? Evidence from emerging country SMEs. International Journal of Logistics Research and Applications, 19(3), pp. 181-199.

[14] Ogbonna, E. \& Harris, L. C. 2000. Leadership style, organizational culture and performance: Empirical evidence from UK companies. International Journal of Human Resource Management, 11(4), pp. 766-788.

[15] Gambi, L. D. N., Boer, H., Gerolamo, M. C., Jørgensen, F. \& Carpinetti, L. C. R. 2015. The relationship between organizational culture and quality techniques, and its impact on operational performance. International Journal of Operations \& Production Management, 35(10), pp. 1460-1484.

[16] Hung, R. Y. Y., Lien, B. Y.-H., Yang, B., Wu, C.-M. \& Kuo, Y.-M. 2011. Impact of TQM and organizational learning on innovation performance in the high-tech industry. International Business Review, 20(2), pp. 213-225.

[17] Saunila, M. 2014. Innovation capability for SME success: Perspectives of financial and operational performance. Journal of Advances in Management Research, 11(2), pp.163-175.

[18] Calantone, R. J., Cavusgil, S. T. \& Zhao, Y. 2002. Learning orientation, firm innovation capability, and firm performance. Industrial Marketing Management, 31(6), pp. 515-524.

[19] López-Nicolás, C. \& Meroño-Cerdán, Á. L. 2011. Strategic knowledge management, innovation and performance. International Journal of Information Management, 31(6), pp. 502-509.

[20] Aboelmaged, M. G. 2014. Linking operations performance to knowledge management capability: The mediating role of innovation performance. Production Planning \& Control, 25(1), pp. 44-58.

[21] Fugate, B. S., Stank, T. P. \& Mentzer, J. T. 2009. Linking improved knowledge management to operational and organizational performance. Journal of Operations Management, 27(3), pp. 247-264.

[22] De Cerio, J. M. D. 2003. Quality management practices and operational performance: Empirical evidence for Spanish industry. International Journal of Production Research, 41(12), pp. 2763-2786.

[23] Truong, H., Sampaio, P., Carvalho, M. D. S., Fernandes, A. C. \& An, D. T. B. 2014. The role of quality management practices in operational performance: An empirical study in a transitional economy. In 1st International Conference on Quality Engineering and Management (ICQEM 2014), pp. 717-733.

[24] Saleh, R. A., Sweis, R. J. \& Mahmoud Saleh, F. I. 2018. Investigating the impact of hard total quality management practices on operational performance in manufacturing organizations: Evidence from Jordan. Benchmarking: An International Journal, 25(7), pp. 2040-2064.

[25] Alhuraish, I., Robledo, C. \& Kobi, A. 2016. Assessment of lean manufacturing and six sigma operation with decision making based on the analytic hierarchy process. IFAC-PapersOnLine, 49(12), pp. 59-64.

[26] Thawani, S. 2004. Six sigma - strategy for organizational excellence. Total Quality Management \& Business Excellence, 15(5-6), pp. 655-664.

[27] Panwar, A., Jain, R., Rathore, A. P. S., Nepal, B. \& Lyons, A. 2018. The impact of lean practices on operational performance: An empirical investigation of Indian process industries. Production Planning \& Control, 29(2), pp. 158-159.

[28] Yadav, V., Jain, R., Mittal, M. L., Panwar, A. \& Lyons, A. 2019. The impact of lean practices on the operational performance of SMEs in India. Industrial Management \& Data Systems, 119(2), pp. 317-330.

[29] Murmura, F., Casolani, N., Liberatore, L. \& Vicentini, A. 2018. An empirical analysis of ISO 9001: 2008 application in Italian services and manufacturing companies. Total Quality Management \& Business Excellence, 29(7-8), pp. 786-797.

[30] Psomas, E. \& Kafetzopoulos, D. 2014. Performance measures of ISO 9001 certified and non-certified manufacturing companies. Benchmarking: An International Journal, 21(5), pp. 756-774.

[31] Anuar, H. S., Zulhumadi, F. \& Udin, Z. M. 2012. The role of internal R\&D in operational performance as moderated by intellectual property rights: The Malaysian manufacturing perspective. Journal of Innovation and Business Best Practices, 2012(1), pp. 1-15.

[32] Moghadam, N. S., Beigi, S. S. \& Ahmadzadeh, M. 2016. Examining the impact of Research and Development Department performance on the profitability of Golkaran Agro-Industrial Company. Management, 3(8), pp. 38-50.

[33] Fok-Yew, O., \& Ahmad, H. (2014). The effect of change management on operational excellence moderated by commitment to change: Evidence from Malaysia. International Journal of Innovation and Applied Studies, 9(2), pp. 615-631.

[34] Fok-Yew, O., Ahmad, H. \& Baharin, S. 2013. Operational excellence and change management in Malaysia context. Journal of Organizational Management Studies, 2013(1), pp. 1-14.

[35] Madapusi, A. \& D'Souza, D. 2012. The influence of ERP system implementation on the operational performance of an organization. International Journal of Information Management, 32(1), pp. 24-34.

[36] HassabElnaby, H. R., Hwang, W. \& Vonderembse, M. A. 2012. The impact of ERP implementation on organizational capabilities and firm performance. Benchmarking: An International Journal, 19(4/5), pp. 618-633. 
[37] Saaty, T. L. 1980. The analytic hierarchy process: Planning, priority setting, resources allocation. McGraw, New York.

[38] Kusumawardani, R. P. \& Agintiara, M. 2015. Application of fuzzy AHP-TOPSIS method for decision making in human resource manager selection process. Procedia Computer Science, 72, pp. 638-646.

[39] Saaty, T. L. 2008. Decision making with the analytic hierarchy process. International Journal of Services Sciences, 1(1), pp. 83-98.

[40] Golden, B. L. \& Wang, Q. 1989. An alternate measure of consistency. In The analytic hierarchy process, pp. 6881. Berlin, Heidelberg: Springer.

[41] Hwang, C. L. \& Yoon, K. 2012. Multiple attribute decision making: Methods and applications A state-of-the-art survey (Vol. 186). Berlin, Heidelberg: Springer Science \& Business Media.

[42] Dağdeviren, M., Yavuz, S. \& Kılınç, N. 2009. Weapon selection using the AHP and TOPSIS methods under fuzzy environment. Expert Systems with Applications, 36(4), pp. 8143-8151. 